\title{
Investigation of the Relationship Between Role Ambiguity and Burnout Levels in Team Athletes
}

\author{
DOI: $10.26466 /$ opus.835438
}

\author{
Soner Çankaya $^{*}$ - Alparslan İnce** - Hacı Ali Çakıc1 ${ }^{* * *}$ - Berkay Mert Özyurt ${ }^{* * * *}$ \\ * Prof. Dr., Ondokuz Mayıs Üni., Yaşar Doğu Spor Bilimleri Fak., Samsun/Türkiye \\ E-Posta: scankaya@omu.edu.tr ORCID: $0000-0001-8056-1892$ \\ ** Doç. Dr., Ordu Üniversitesi, Beden Eğitimi ve Spor Y. O, Ordu/Türkiye \\ E-Posta: ftrbesyo@hotmail.com ORCID: 0000-0003-1617-4809 \\ *** Arş.Gör., Ondokuz Mayıs Üni., Yaşar Doğu Spor Bilimleri Fakültesi, Samsun/Türkiye \\ E-Posta: cakicihaciali@gmail.com ORCID: $\underline{0000-0001-9439-1118}$ \\ **** Yl. Öğr Ondokuz Mayıs Üni., Yaşar Doğu Spor Bilimleri Fak., Samsun/Türkiye \\ E-Posta: berkaymertozyurt4@gmail.com ORCID: 0000-0001-7694-1606
}

\begin{abstract}
The aim of this study is to analyse the relationship between role ambiguity and burnout levels in team athletes. Descriptive relational survey model was used in the study. The population of the study consists of team sports athletes studying at Ondokuz Mayıs University Yaşar Doğu Faculty of Sports Sciences. The sample of the study consists of 161 team sports athletes chosen with random sampling method among the students of the aforementioned faculty. In the study, "Role Ambiguity Scale" and "The Sport Burnout Inventory" were used as data collection instrument. As a result of the analysis conducted, no significant difference was found between the groups in terms of the variables of gender and state of income. While significant difference was found in the sub-dimension of "Role Responsibility and Performance Criterion", no difference was found in the other sub-dimensions. Weak and moderate significant associations were found between total scores of the answers given by athletes to role ambiguity and burnout scales. According to the results of the study, it can be said that the ambiguity of the responsibilities of athletes has an influence on burnout levels. Thus, it is thought that misdirection of decision makers in team sports for the responsibilities of athletes can cause negative effects on the athletes' burnout levels.
\end{abstract}

Keywors: Sports, role ambiguity, burnout 


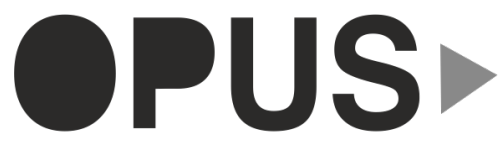

Uluslararası Toplum Araştırmaları Dergisi International Journal of Society Researches
E-ISSN : 2528-9535

YIl Year: 11

Cilt Volume: 18

Sayı Issue :39

Temmuz July 2021

Makalenin Geliş Tarihi Received Date: 03/12/2020

Makalenin Kabul Tarihi Accepted Date: 20/04/2021

\section{Takım Sporları ile İlgilenen Sporcularda Rol Belirsizliği ile Tükenmişlik Düzeyleri Arasındaki İlişkinin İncelenmesi}

Öz

Bu çalışmanın amacı takım sporcularının rol belirsizliği ile tükenmişlik düzeyleri arasındaki ilişkinin incelenmesidir. Çalışmada betimsel nitelik taşıyan ilişkisel tarama modeli kullanılmıştır. Araştırmanın evreni, Ondokuz Mayıs Üniversitesi Yaşar Doğu Spor Bilimleri Fakültesi'nde öğrenim gören takım sporcuları oluşturmaktadır. Araştırmanın örneklemini ise, belirtilen fakülteden tesadüfi örneklem yöntemi ile seçilen 161 takım sporcusu oluşturmaktadır. Çalışmada veri toplama aracı olarak "Rol Belirsizliği envanteri ile "Spor Tükenmişliği Envanteri" kullanılmıştır. Yapılan analiz neticesinde cinsiyet ve gelir durumu değişkenine göre gruplar arasinda farklılık tespit edilmemiştir. Rol belirsizliği alt boyutlarndan biri olan "Rolün Getirdiklerini Bilme" alt boyutunda anlaml düzeyde farkllaşma tespit edilirken, diğer alt boyutlarda farklılık bulunmamıştır. Sporcuların rol belirsizliği ve tükenmişlik ölçeklerine verdikleri cevaplara ait toplam puanlar arasında zayıf ve orta düzeyde anlaml ilişkiler tespit edilmiştir. Bu çalışma sonucuna göre sporcularm üstlenmiş oldukları rollerin belirsizliklerinin tükenmiş̧lik düzeylerine etki ettiği söylenebilir. Dolayısıyla, takım sporlarında karar vericilerin sporculara karşı üstlenecekleri roller hususunda yanlış yönlendirmeler yapmaları, onların tükenmişlik düzeylerinde olumsuz etki oluşturabilir.

AnahtarKelimeler: Spor, rol belirsizliği, tükenmişlik. 


\section{Introduction}

Today, as a result of match analysis for team sports, it is known that the positions played by athletes or the roles they have undertaken are effective on teams' success in competitions. The roles athletes have undertaken have very big significance in revealing their performance and abilities better. It is thought that role ambiguity, which is the exact opposite of this situation, will have negative effects on athletes' performances. Role ambiguity is defined as individuals' not having enough information about the behaviours they will show or in the roles they will undertake and the individuals' not knowing what is expected of them (Sager, 1994). This situation can be expressed as individuals' not being able to perceive clearly the responsibilities given to them. According to Sawyer (1992), if individuals know the method to fulfil their responsibilities or roles, they will know how to get away from role ambiguity. Similarly, it is also obvious in sport that for athletes to successfully fulfil the roles attributed to them, they should know how to fulfil those roles. It can be said that role ambiguity will have negative effects on mental burnout levels of athletes in addition to their success. Burnout is explained as fatigue, low level of success and energy depletion of individuals in the face of excessive demands (Freudenberger, 1975). Burnout in sport is defined as frustration and physical and mental fatigue of athletes resulting from intense participation in sport activities (Raedeke and Smith, 2001). As the level of burnout increases in athletes, it can be said that this will adversely affect their loyalty to sports, their stress, role confusion and role ambiguity.

When studies conducted on role ambiguity in the field of sport sciences are examined, studies conducted after 2000s can be found. It can be seen that studies conducted are on areas such as cognitive and somatic anxiety (Beauchamp, Bray, Eys and Carron, 2003); role conflict (Beauchamp and Bray, 2001) and social loafing (Hoigaard, Fuglestad, Peters, Cuyper, Backer and Boen, 2010). The aim of this study is to define the relationship between athletes' burnout levels and their states of having sufficient information about the behaviours they show and knowing what is expected of them. 


\section{Material And Method}

In the study, approval was taken from Ondokuz Mayıs University Social and Human Sciences Ethics Committee with 20/12/2019 dated and 2019/438 numbered decision to apply the scales and collect the data.

\section{Research Model}

This study is a descriptive study with relational survey model. In studies with survey model, an existing situation is described as it is (Karasar, 2009). In studies based on relational survey model, the aim is "to analyse the relationship between two or more variables without interfering with these variables" (Büyüköztürk et al., 2010). The present study analysed the association between athletes' role ambiguity and burnout levels. Statistical analyses were used to find out whether role ambiguity and burnout levels of athletes differed in terms of their demographic information and to find out the association between these.

\section{Population and Sample of the Study}

The population of the study consists of sub-elite team sports athletes (Rugby, Football, Volleyball, Basketball, Handball) studying at Samsun Ondokuz Mayıs University Yaşar Doğu Faculty of Sport Sciences. The sample of the study consists of 161 team sports athletes who were chosen with random sampling method among students studying at Samsun Ondokuz Mayıs University Yaşar Doğu Faculty of Sport Sciences.

\section{Data Collection Instruments}

A personal information form prepared by the researchers, and two scales, the validity and reliability studies of which had been conducted (Role Ambiguity Scale and The Sport Burnout Inventory), were used in the study.

Personal information form consists of items to find out the age, gender, family income level, sport age, duration of injury and branch of the 
athletes who participated in the study. Role Ambiguity Scale, which was developed by Beauchamp and Bray (2001) and which was adapted by Davarc1 (2008), has 7 items. This scale, which was developed to find out role ambiguity of athletes, has two sub-dimensions. These are "Role Responsibility and Performance Criterion" and "Knowing of Role Requirement". Cronbach's Alpha coefficients for the 7-Likert type measurement instrument were .77 for Role Responsibility and Performance Criterion sub-dimension and .72 for Knowing of Role Requirement subdimension.

Sport Burnout Inventory: The inventory which was developed by Salmela-Aro et al. (2009) under the name "School Burnout Inventory" to find out the school exhaustion levels of students was adapted to the field of sport by Sorkkila et al. (2017). The inventory was adapted into Turkish culture by Çam et al. (2019). Sport Burnout Inventory consists of three sub-dimensions. These are "cynicism", "exhaustion" and "inadequacy". High scores taken from Sport Burnout Inventory, which is a 5-Likert type measurement instrument, shows that the participant's burn out level is high.

\section{Data Analysis}

In the study, reliability coefficients (Cronbach's Alpha coefficients) were found to check the internal consistency of the answers given to scale items. The estimated reliability coefficient was 0,872 for Role Ambiguity Scale which was given to athletes who participated in the study voluntarily; in terms of sub-dimensions, reliability coefficient was found as 0,919 for Role Responsibility and Performance Criterion and as 0,628 for Knowing of Role Requirement. Estimated reliability coefficient for Sport Burnout Inventory was 0,883; in terms of sub-dimensions, reliability coefficient was found as 0,770 for exhaustion, as 0,802 for cynicism and as 0,627 for inadequacy. In data analysis, the assumption normality was evaluated with Kolmogorov-Smirnov and Shapiro-Wilk test $(\mathrm{P}<0,05)$. Mann Whitney $U$ test was used to find out differences between the scores for gender, while Kruskal Wallis $\mathrm{H}$ test was used to find out the differences among the scores for level of income and branches. The relationship between athletes' role ambiguity and burnout levels was ana- 
lysed with Kendall's tau b correlation coefficient. SPSS 21.0 V. (Statistical Package For Social Scientists for Windows Release 21) statistical program was used for the analysis of data obtained from the study and the results were considered as significant at $\mathrm{P}<0,05$ level.

\section{Results}

The statistics relating to the differences among total scores and subdimension scores of role ambiguity and burnout levels of team athletes studying at Ondokuz Mayis University in terms of the athletes' gender, age, sport age, level of income, branch and duration of injury were presented in Table 1-3, while the correlations between the scales (Role Ambiguity in Athletes and Sport Burnout Inventory) was presented in Table 4.

Table 1. Athletes' role ambiguity and burnout levels in terms of gender

\begin{tabular}{llllllll}
\hline & Gender & $\mathrm{n}$ & Mean & SD & Median & IQR & P \\
\hline Knowing of Role Require- & Male & 98 & 6,30 & 3,83 & 5,00 & 6,00 & 0,181 \\
ment & Female & 63 & 6,73 & 3,35 & 6,00 & 5,00 & \\
\hline Role Responsibility and & Male & 98 & 8,54 & 5,88 & 7,00 & 6,00 & 0,490 \\
Performance Criterion & Female & 63 & 7,74 & 5,31 & 6,00 & 5,00 & \\
\hline Role Ambiguity Total Score & Male & 98 & 14,84 & 8,90 & 12,00 & 11,25 & 0,656 \\
& Female & 63 & 14,47 & 7,53 & 14,00 & 9,00 & \\
\hline Exhaustion & Male & 98 & 8,70 & 3,66 & 8,00 & 5,00 & 0,246 \\
& Female & 63 & 9,42 & 3,88 & 8,00 & 4,00 & \\
\hline Cynicism & Male & 98 & 6,03 & 3,06 & 5,00 & 5,00 & 0,405 \\
& Female & 63 & 6,34 & 3,00 & 6,00 & 4,00 & \\
\hline Inadequacy & Male & 98 & 7,90 & 3,10 & 8,00 & 5,00 & 0,681 \\
& Female & 63 & 7,69 & 2,87 & 8,00 & 4,00 & \\
\hline Sport Burnout Total Score & Male & 98 & 22,64 & 8,61 & 22,00 & 13,00 & 0,682 \\
& Female & 63 & 23,47 & 8,88 & 23,00 & 10,00 & \\
\hline
\end{tabular}

Table 1 shows that no significant difference was found in male and female athletes' role ambiguity scale and sport burnout inventory total score and sub-dimension scores according to Mann Whitney U test results $(\mathrm{P}>0,05)$. 
Table 2. Athletes' role ambiguity and burnout levels in terms of family level of income

\begin{tabular}{llllllll}
\hline & $\begin{array}{l}\text { Family level of } \\
\text { income }\end{array}$ & $\mathrm{n}$ & Mean & $\mathrm{SD}$ & Median & IQR & $\mathrm{P}$ \\
& & & & & & \\
\hline Knowing of Role & Income>Expense & 18 & 5,55 & 3,60 & 3,50 & 5,25 & 0,090 \\
Requirement & Income=Expense & 128 & 6,46 & 3,67 & 5,00 & 6,00 & \\
& Income<Expense & 15 & 7,66 & 3,37 & 7,00 & 6,00 & \\
\hline Role Responsibility & Income>Expense & 18 & 7,27 & 4,84 & 5,50 & 4,25 & 0,492 \\
and Performance & Income=Expense & 128 & 8,08 & 5,33 & 7,00 & 5,00 & \\
Criterion & Income<Expense & 15 & 10,60 & 8,52 & 8,00 & 9,00 & \\
\hline Role Ambiguity Total & Income>Expense & 18 & 12,83 & 8,03 & 10,00 & 9,75 & 0,175 \\
Score & Income=Expense & 128 & 14,54 & 8,02 & 13,00 & 10,00 & \\
& Income<Expense & 15 & 18,26 & 10,95 & 14,00 & 13,00 & \\
\hline Exhaustion & Income>Expense & 18 & 8,16 & 4,13 & 7,50 & 6,00 & 0,443 \\
& Income=Expense & 128 & 9,05 & 3,69 & 8,00 & 5,00 & \\
& Income<Expense & 15 & 9,40 & 3,94 & 8,00 & 4,00 & \\
\hline Cynicism & Income>Expense & 18 & 5,38 & 2,78 & 4,50 & 4,50 & 0,395 \\
& Income=Expense & 128 & 6,19 & 3,01 & 6,00 & 5,00 & \\
& Income<Expense & 15 & 6,73 & 3,47 & 5,00 & 5,00 & \\
\hline Inadequacy & Income>Expense & 18 & 7,38 & 3,12 & 7,50 & 5,50 & 0,780 \\
& Income=Expense & 128 & 7,92 & 3,03 & 8,00 & 4,00 & \\
& Income<Expense & 15 & 7,53 & 2,77 & 8,00 & 4,00 & \\
\hline Sport Burnout Total & Income>Expense & 18 & 20,94 & 9,31 & 18,00 & 15,75 & \multirow{2}{*}{0,443} \\
& Income=Expense & 128 & 23,17 & 8,62 & 23,00 & 11,00 & \\
\hline & Income<Expense & 15 & 23,66 & 8,62 & 22,00 & 8,00 & \\
\hline
\end{tabular}

Kruskal Wallis $\mathrm{H}$ test results showed that no significant difference was found in role ambiguity scale and sport burnout inventory total score and sub-dimension scores in terms of the athletes' family income level $(\mathrm{P}>0,05)$ (Table 2).

Table 3. Athletes' Role Ambiguity and Burnout Levels in terms of branches

\begin{tabular}{llllllll}
\hline & Branch & $\mathrm{n}$ & Mean & $\mathrm{SD}$ & Median & IQR & $\mathrm{P}$ \\
\hline & Rugby & 33 & 6,72 & 3,62 & $6,00 \mathrm{~b}$ & 6,00 & \\
Knowing of Role Re- & Football & 47 & 5,36 & 3,19 & $4,00 \mathrm{c}$ & 5,00 & \\
quirement & Volleyball & 28 & 7,57 & 3,19 & $7,00 \mathrm{a}$ & 6,00 & 0,045 \\
& Basketball & 31 & 7,32 & 4,30 & $6,00 \mathrm{~b}$ & 7,00 & \\
& Handball & 22 & 5,86 & 2,56 & $5,00 \mathrm{c}$ & 4,25 & \\
\hline \multirow{5}{*}{$\begin{array}{l}\text { Role Responsibility and } \\
\text { Performance Criterion }\end{array}$} & Rugby & 33 & 9,33 & 6,54 & 7,00 & 6,00 & \\
& Football & 47 & 7,55 & 5,32 & 6,00 & 4,00 & \multirow{2}{*}{0,258} \\
& Volleyball & 28 & 7,96 & 5,14 & 7,00 & 5,00 & \\
\hline \multirow{2}{*}{$\begin{array}{l}\text { Role Ambiguity Total } \\
\text { Score }\end{array}$} & Hasketball & 31 & 9,32 & 6,21 & 8,00 & 6,00 & \\
& Rugby & 33 & 16,06 & 9,36 & 14,00 & 12,00 & \multirow{2}{*}{0,140}
\end{tabular}




\begin{tabular}{llllllll} 
& Volleyball & 28 & 15,53 & 8,43 & 14,00 & 12,25 & \\
& Basketball & 31 & 16,64 & 9,46 & 14,00 & 12,00 & \\
& Handball & 22 & 12,68 & 6,19 & 11,00 & 6,25 & \\
\hline \multirow{5}{*}{ Exhaustion } & Rugby & 33 & 8,57 & 3,24 & 8,00 & 3,50 & \\
& Football & 47 & 9,31 & 4,81 & 8,00 & 9,00 & \\
& Volleyball & 28 & 9,39 & 3,78 & 9,00 & 6,25 & 0,847 \\
& Basketball & 31 & 9,03 & 2,86 & 9,00 & 4,00 & \\
& Handball & 22 & 8,31 & 3,06 & 8,00 & 5,00 & \\
\hline \multirow{5}{*}{ Cynicism } & Rugby & 33 & 6,12 & 2,81 & 6,00 & 5,00 & \\
& Football & 47 & 6,59 & 3,79 & 6,00 & 6,00 & \\
& Volleyball & 28 & 6,25 & 2,92 & 5,50 & 5,50 & 0,969 \\
& Basketball & 31 & 5,74 & 2,25 & 6,00 & 4,00 & \\
& Handball & 22 & 5,72 & 2,74 & 5,00 & 5,25 & \\
\hline \multirow{5}{*}{ Inadequacy } & Rugby & 33 & 7,81 & 3,15 & 8,00 & 4,50 & \\
& Football & 47 & 8,04 & 3,49 & 8,00 & 6,00 & \\
& Volleyball & 28 & 7,71 & 2,70 & 8,00 & 4,75 & 0,957 \\
Sport Burnout Total & Basketball & 31 & 7,96 & 2,70 & 8,00 & 4,00 & \\
& Handball & 22 & 7,31 & 2,69 & 8,00 & 5,00 & \\
& Rugby & 33 & 22,51 & 7,76 & 22,00 & 12,50 & \\
& Football & 47 & 23,95 & 11,09 & 22,00 & 20,00 & \\
& Volleyball & 28 & 23,35 & 8,87 & 23,00 & 13,00 & 0,944 \\
& Basketball & 31 & 22,74 & 6,28 & 23,00 & 9,00 & \\
& Handball & 22 & 21,36 & 7,24 & 21,00 & 11,50 & \\
\hline
\end{tabular}

Kruskal Wallis $\mathrm{H}$ test results showed that no significant difference was found in role ambiguity scale and sport burnout inventory total score and sub-dimension scores of the athletes except for Knowing of Role Requirement scores in terms of the athletes' branch (Table 3). While volleyball players had the highest knowing of role requirement scores, football and handball players had the lowest.

No significant association was found between some demographic characteristics (age, sport age and injury time) and role ambiguity and burnout level total scores of the athletes who participated in the study ( $P>0,05$; Table 4). However, weak (for example: $r=0,257$ for SBTS and $\mathrm{KRR}$; $\mathrm{r}=0,241$ for $\mathrm{E}$ and $\mathrm{KRR}$ etc.), and moderate significant correlations (for example: $\mathrm{r}=0,311$ for SBTS and RATS; $\mathrm{r}=0,324$ for SBTS and RRPC; $\mathrm{r}=0,303$ for $\mathrm{E}$ and RATS etc.) were found between total scores of athletes' answers to role ambiguity and burnout scales $(\mathrm{P}<0,001$; Table 4$)$. 
Table 4. Levels of association between athletes' demographic characteristics and role ambiguity and sport burnout scores

\begin{tabular}{lllllllllll}
\hline & & Age & SA & I & RATS & KRR & RRPC & SBTS & E & C \\
\hline SA & $\mathrm{r}$ &, 153 & & & & & & & & \\
& $\mathrm{p}$ &, 011 & & & & & & & & \\
I & $\mathrm{r}$ &, 095 &, 116 & & & & & & & \\
& $\mathrm{p}$ &, 144 &, 065 & & & & & & & \\
RATS & $\mathrm{r}$ &,- 030 &,- 031 &,- 057 & & & & & & \\
& $\mathrm{p}$ &, 618 &, 587 &, 359 & & & & & & \\
KRR & $\mathrm{r}$ &,- 028 &,- 043 &,- 074 &, 772 & & & & & \\
& $\mathrm{p}$ &, 651 &, 467 &, 246 & $<, 001$ & & & & & \\
& $\mathrm{r}$ &,- 014 &,- 029 &,- 030 &, 768 &, 491 & & & & \\
& $\mathrm{p}$ &, 823 &, 627 &, 640 & $<, 001$ & $<, 001$ & & & & \\
RRPC & $\mathrm{r}$ &, 037 &, 014 &,- 069 &, 311 &, 257 &, 324 & & & \\
SBTS & $\mathrm{p}$ &, 522 &, 802 &, 259 &, 000 &, 000 &, 000 & & & \\
& $\mathrm{r}$ &, 054 &, 023 &,- 072 &, 303 &, 241 &, 317 &, 758 & & \\
E & $\mathrm{p}$ &, 370 &, 687 &, 248 & $<, 001$ & $<, 001$ & $<, 001$ & $<, 001$ & & \\
& $\mathrm{r}$ &, 050 &, 079 &,- 005 &, 284 &, 255 &, 271 &, 767 &, 601 & \\
C & $\mathrm{p}$ &, 412 &, 181 &, 944 & $<, 001$ & $<, 001$ & $<, 001$ & $<, 001$ & $<, 001$ & \\
& $\mathrm{r}$ &, 005 &,- 052 &,- 104 &, 230 &, 178 &, 285 &, 719 &, 491 &, 557 \\
IA & $\mathrm{p}$ &, 928 &, 367 &, 098 & $<, 001$ &, 002 & $<, 001$ & $<, 001$ & $<, 001$ & $<, 001$ \\
\hline
\end{tabular}

SA: Sport age; I: Injury; RATS: Role Ambiguity Total Score; KRR: Knowing of Role Requirement; RRPC: Role Responsibility and Performance Criterion; SBTS: Sport Burnout Total Score; E: Exhaustion; C: Cynicism; IA: Inadequacy

\section{Discussion And Conclusion}

This study was conducted to find out the association between role ambiguity and burnout levels of team athlete students attending Samsun Ondokuz Mayıs University Yaşar Doğu Faculty of Sport Sciences during 2019-2020 Academic Year. While no significant difference was found in the scales used in terms of the variables of gender and level of education, significant difference was found only in knowing of responsibility subdimension of role ambiguity scale in terms of the variable of branch.

In the study, when role ambiguity and sport burnout inventory subdimensions and total scores were examined in terms of the variable of gender, no significant difference was found. According to this result, it can be said that role ambiguity and burnout states of men and women have the same level of effect. When studies conducted on role ambiguity are examined, it can be said that no significant difference was found in the study conducted on athletes by Davarc1 (2008). This result is in parallel with the results of the present study. Significant difference was found 
in terms of the variable of gender in a study conducted on bank employees by Ok (2004) and this result was not in parallel with the results of the present study. When studies conducted on burnout are examined, it can be said that the results of the studies conducted by Bayköse et al. (2019) and Medeni (2018) are not in parallel with the results of the present study. When the literature was reviewed, it was found that significant differences were found in terms of the variable of gender in studies conducted by Akbulut (2018), Özcoşan (2018), Çalışkan (2019), Dağcı (2019) and Gök (2019). These results are not similar to the results of the present study.

When role ambiguity and sport burnout inventory sub-dimensions and total scores were examined in terms of the variable of income level, no significant difference was found. According to this result, it can be said that all income level categories have the same level of effect on role ambiguity and burnout states. When the literature is reviewed, no studies were found on role ambiguity in terms of the variable of level of income. In terms of burnout levels, the results of the study conducted by Dağ $\mathrm{Cl}$ (2019) and the results of the present study are similar. In a study by Türkman (2017), significant difference was found in emotional burnout sub-dimension in terms of the variable of level of income. This result is not partly in parallel with the results of the present study.

While no significant difference was found in sport burnout inventory sub-dimensions and total scores in terms of the variable of branch, significant difference was found in knowing of role requirement in role ambiguity scale. According to this result, score averages of volleyball players were found to be higher than the score averages of other branches. This result can be due to the fact that other branch categories have more struggles in them and are tougher than volleyball and that athletes are more careful in fulfilling their roles. When the literature about role ambiguity was reviewed, no significant difference was found in a study conducted on athletes by Davarc1 (2008). When the literature about burnout was reviewed, significant difference was found in Özcoşan (2018)'s study in terms of the variable of branch. The results found are not in parallel with the results of our study.

When the correlation coefficient results of the variables of age, sport age and duration of injury were examined, no significant association was 
found between role ambiguity and burnout levels. A moderate significant association was found between athletes' role ambiguity and burnout levels. Therefore, it can be said that the ambiguity of the positions of the athletes, that is their roles, has an effect on their burnout levels, even if partially. As a result, it can be said that misdirection of decision makers (trainer, club manager, president, etc.) about the roles athletes will assume, especially in team sports will have a negative effect on athletes' burnout levels. In addition, according to the results of the study, it is thought that directing the athletes to their roles in the team by considering their performance and athletes' adapting these roles will minimize their burnout levels and contribute to the integrity of the team.

\section{References}

Akbulut, A., (2018). Taekwondo ve boks antrenörlerinin tükenmişlik düzeylerinin karşılaştırılması (Yüksek Lisans Tezi). Akdeniz Üniversitesi, Sağlık Bilimler Enstitüsü, Antalya.

Beauchamp, M.R., Bray, S.R., Eys, M.A. and Carron, A.V. (2003). The effect of role ambiguity on competitive state anxiety. Journal of Sport \& Exercise Psychology, 25, 77-92. Doi: 10.1123/jsep.25.1.77

Bayköse, N., Turan, E.B., Turan, E., Şahan, H. (2019). Muay thai antrenörlerinin tutkunluk ve yaşam doyumlarının tükenmişlik düzeylerine etkisi. Akdeniz Spor Bilimleri Dergisi, 2(1), 58,66.

Beauchamp, MR., and Bray, SR. (2001). Role ambiguity and role conflict within interdependent teams. Small Group Research,32,133. Doi: $10.1177 / 104649640103200202$

Büyüköztürk, Ş., Kılıç-Çakmak, E., Akgün, Ö. E., Karadeniz, Ş., ve Demirel, F. (2010). Bilimsel araştırma yöntemleri. Ankara: Pegem Akademi.

Çalışkan, S. (2019). Öğretmenlerin tükenmişlik ve iş doyumu düzeyleri arasındaki ilişki (Yüksek Lisans Tezi). Ondokuz Mayıs Üniversitesi, Eğitim Bilimleri Enstitüsü, Samsun.

Çam, Z., Kardaş, F., Eşkisu, M., ve Gelibolu, S. (2019). Spor tükenmişliği envanteri'nin Türk kültürüne uyarlanması ve psikometrik özellikleri. СВӤ Beden Eğitimi ve Spor Bilimleri Dergisi, 14(11), 80,96. Doi: https://dergipark.org.tr/download/article-file/741717 
Dağcl, A. (2019). Öğretmenlerin tükenmişlik düzeyi ve tükenmişliğin okul yönetimiyle ilgili boyutlarnna ilişkin karma bir araştırma. (Yüksek Lisans Tezi).Maltepe Üniversitesi, Sosyal Bilimler Enstitüsü, İstanbul.

Davarcı S. (2008). Sporcularda rol belirsizliğinin grup bütünlüğ̈̈ne etkisi. (Yüksek Lisans Tezi). Mersin Üniversitesi, Sağlık Bilimleri Enstitüsü, Mersin.

Freudenberger, H. J. (1975). The staff burn-out syndrome in alternative institutions. Psychotherap. Theory, Research \& Practice, 12(1), 73-82. Doi: 10.1037 / h0086411

Gök, A. (2019). Beden eğitimi ve spor öğretmenlerinin iş doyumu ve tükenmişlik düzeyleri arasındaki ilişki, neden ve çözüm önerilerinin belirlenerek farklı değişkenlere göre karşılaştırılması. (Yüksek Lisans Tezi). Burdur Mehmet Akif Ersoy Üniversitesi, Eğitim Bilimleri Enstitüsü, Burdur.

Hoigaard, R., Fuglestad, S., Peters, D.M., Cuyper, B.D., Backer, M.D., and Boen, F., (2010). Role satisfaction mediates the relation between role ambiguity and social loafing among elite women handball players. Journal of Applied Sport Psychology, 22, 408-419. Doi: https://doi.org/10.1080/10413200.2010.495326

Karasar, N. (2009). Bilimsel araştırma yöntemi (19. baskı). Ankara: Nobel.

Medeni, M.B. (2018). Beden eğitimi ve spor öğretmenlerinin tükenmişlik düzeylerinin incelenmesi (Balıkesir ili örneği.) (Yüksek Lisans Tezi). Balıkesir Üniversitesi, Sağlık Bilimleri Enstitüsü, Balıkesir.

Ok, S. (2004). Banka çalışanlarının tükenmişlik düzeylerinin iş doyumu, rol çatışması, rol belirsizliği ve bazı bireysel özelliklere göre incelenmesi. Türk psikolojik danışma ve rehberlik dergisi, 3(21), 57-67. Doi: https://dergipark.org.tr/tr/pub/tpdrd/issue/21441/229660

Özcoşan, V. (2018). Farklı spor dallarındaki sporcuların tükenmişlik düzeylerinin bazı değişkenlere göre araştırılması. (Yüksek Lisans Tezi). Dumlupınar Üniversitesi, Sağllk Bilimler Enstitüsü, Kütahya.

Raedeke, T.D., and Smith A.L. (2001). Development and preliminary validation of an athlete burnout measure. Journal of Sport and Exercise Psycho$\log y, 23,281-306$. Doi: 10.1123/jsep.23.4.281

Sager, J.K. (1994), "A structural model depicting salespeople's job stress", Journal of the Academy of Marketing Science, 22(1), 74-84. Doi: https://doi.org/10.1177/0092070394221007

Salmela-Aro, K., Kiuru, N., Leskinen, E., and Nurmi, J. E. (2009). School burnout inventory (SBI) reliability and validity. European Journal of Psychological Assessment, 25(1), 48-57. Doi: 10.1027/1015-5759.25.1.48 
Sawyer, J.E. (1992). Goal and process clarity: Specification of multiple constructs of role ambiguity and a structural equation model of their antecedents and consequences. Journal of Applied Psychology, 77(2), 130-142. Doi: 10.1037/0021-9010.77.2.130

Sorkkila, M., Ryba, T. V., Aunola, K., Selänne, H., and Salmela-Aro, K. (2017). Sport burnout inventory dual career form for student-athletes: Assessing validity and reliability in a Finnish sample of student athletes. Journal of Sport and Health Science, 9(4),1-9. Doi : 10.1016/j.jshs.2017.10.006

Türkman, M.A. (2017). Büyükler Türkiye güreş şampiyonasına katılan güreş antrenörlerinin mesleki tükenmişlik düzeylerinin sosyo demografik özelliklerine göre değerlendirilmesi. (Yüksek Lisans Tezi). İstanbul Gelişim Üniversitesi, Sağlık Bilimleri Enstitüsü, İstanbul.

\section{Kaynakça Bilgisi / Citation Information}

Çankaya, S., İnce, A. , Çakıcı, H. A. ve Özyurt, B. M. (2021) Investigation of the relationship between role ambiguity and burnout levels in team athletes. OPUS-International Journal of Society Researches, 18(39), 47-59. DOI: 10.26466/opus. 835438 